\title{
Évindító megújuló lapszám 113 éve és most
}

\author{
Inaugural issue 113 years before and now
}

\author{
Szerzők: Kovács Piroska $₫$, Solymosy József Bonifácz \\ Nemzeti Egészségfejlesztési Intézet
}

Kulcsszavak: egészség, egészségkultúra, kritikus olvasás

Egészség XVII. ÉVF.109. füzet. Január 15 1903.I. füzet.

Csak természetes, ha az ember az új év kezdetén így sóhajt föl : Egészséget adj nekem Istenem!

Van-e, képzelhető-e ember, a ki ne egészségének tartósságát, vagy még inkább, ha beteg, ne annak visszanyerését kivánná mindenek fölött? És valóban örök igazság marad az, hogy a legnagyobb földi kincs az egészség. Többet ér az minden vagyonnál, ragnál, hatalomnál. Alapja az az örömnek. a megelégedésnek, a boldogságnak, mert ezek csak amannak izmos törzse, lombokkal dús ágai alatt virulhatnak. Éltető ereje nélkül elcsenevészedik, kivesz minden. Egészség nélkül az élet teher, a földi javak élvezhetetlenek. A kinek pedig a sors anyagiakat sem jutatott, annak aztán még sokszorta gyötrelmesebb az élete.

És mégis, mily kevesen törődnek egészségükkel; és általában a múveltebb ember is mily keveset érdeklődik az egészség megóvására irányuló törekvések iránt.

Sajátságos vonása az embernek, hogy a mikor teste minden külső és belső része jól teljesíti kötelességét, mikor egészséges, akkor ismeri fel legkevésbé az egészségnek nagy és mindenekfölött való értékét. Mikor ellenben megbetegszik, legyen bár csekélyebb jelentőségú a betegsége, azonnal észreveszi, hogy elvesztette a legdrágább kincsét.

$\mathrm{Az}$ is furcsa vonása az embernek, hogy a mikor elveszti egészségét. ennek a legdrágább kincsének a visszaszerzésére hajlandó minden módjában álló eszközt mozgositani, minden tőle telhető áldozatot meghozni. Ellenben mikor jól érzi magát, az egészsége megóvására szolgáló és jelentékenyen kevesebb áldozatokat igénylő életmódot nem követi. Semmibe sem veszi az orvosnak, az egészségtudo- mány hivatott múvelőjének a lakásra, a táplálkozásra, a ruházatra, a test ápolására, a munkára s az egészségét közvetlenül érintő más sok egyébre vonatkozó tanácsait.

Sajnos, az egészségügyi dolgokkal való nemtörődömség vádjával nagyon sokakat illethetünk. De sőt maga az állam sem fordít az egészségügyre annyi gondot, nem hoz érette annyi áldozatot, mint a mennyit arra fordítania kellene! Egy-egy pusztító járvány kell ahhoz, hogy időnkint a közegészségügyért is tegyenek valamit.

A mi egyesületünk igazán szerény eszközeivel immár a tizenhetedik esztendeje küzd népünk egészségügyének javításáért.

Az Egészség mai füzetével e hasznos folyóiratnak tizenhetedik évfolyamát kezdjük meg.

Továbbra is az Országos Közegészségügyi Egyesület beszélő organuma kiván lenni az Egészség, a melyben számot adunk mindarról, a mit egyesületünk körében teszünk egészségügyünk javítása érdekében. Az Egészség útján világosítjuk föl tagjainkat és olvasóinkat a köz- és magánegészségügy körébe tartozó kérdésekről.

Folyóiratunkkal oktatni akarjuk olvasóinkat, mert bármennyire múvelt legyen is valaki, mindent nem tudhat; és soha sem szégyen az, ha tanulunk. Más részről épen egészségügyi kérdésekben sokaknak hiányos az ismeretük, vagy a mi talán még rosszabb, hibás.

Olvassák tagjaink és előfizetőink az Egészséget, de adják oda másoknak is, hogy olvassák.

Támogassák a mi törekvésünket tagok gyűjtésével is!

Kérjük, hogy használják fel az ezen füzethez, mellékelt tagot-bejelentő szelvénykét! 
Ha minden tagunk csak egy új tagot szerez, azzal már jelentékeny szolgálatot tesz egészségügyünknek, mert az Országos Közösségi Egyesület minden tagja harcosa nemzetünk egészségügyének.

Nézzék át egyesületünk tagjainak az Egészség mult évi füzeteiben közzétett névjegyzékét: abból megláthatják, hogy kikkel állanak egy seregben, de megláthatják azt is, hogy ismerőseik közül ki nincs még benn a seregben.

Rajta! Toborozzanak!
Ahogy 1903-ban, úgy ma is szerepel a jókívánságok között az egészség. Ma már tudjuk, hogy az egészségért nem csak fohászkodni lehet, hanem tudatosan is lehet tenni érte és nem csak az egyén, de a társadalmi-gazdasági-kulturális környezet is felel a minőségéért. Az egyén számára „az egészséget valós tőkeként kell értelmeznünk az egyén és a társadalom szintjén, vagyonként, erőforrásként, olyan értékként, melyre vigyáznunk és fejlesztenünk kell”. ${ }^{1}$ Gazdasági szempontból vizsgálva: „[...] a gazdasági fejlettség és az egészségi állapot közötti öszszefüggés kétirányú: a népesség egészségi állapota - és így maga az egészségügyi rendszer is - alapvetően befolyásolja a hosszú távú gazdasági növekedést." ${ }^{2} A z$ elkerülhető halálozás tényezői között jelentős tényező az egészségügyi kapacitások és az ellátásra szoruló egyének igénybevételi hajlandósága (egészségkultúrája). ${ }^{3} \mathrm{Az}$ egészségkultúra (health literacy), az egyén szintjén magában foglalja a képességet, hogy az egyén a számára fontos információkhoz hozzáférjen, megértse és tudja értékelni, valamint kommunikálni is azokat annak érdekében, hogy saját egészségét élete során különböző helyzetekben fenntartsa és fejlessze. A társadalom szintjén viszont a szolgáltatások és elérhetőségük, a természetes és mesterséges környezet milyensége, a társadalmi (igazságos) elosztási/újraelosztási rendszerek együttesen képezik az egészségkultúra részét. A 113 évvel ezelőtti folyóirati oktatási szándéka ma is méltányolható, a mostani megújult Egészségfejlesztés folyóirat azonban inkább a szakmai párbeszéd megindítását, fenntartását célozza. Nem toborzunk egyesületi tagokat, de azt kérjük, hogy ajánlják olvasásra másnak is. 113 évvel ezelőtt, az egészség ügyének szolgálatát még az egyesületi tagtoborzásban látták: „Ha minden tagunk csak egy új tagot szerez, azzal már jelentékeny szolgálatot tesz egészségügyünknek". Ma már az olvasótábor bővülésében hiszünk inkább, az egészség ügyének szolgálatában, az egészségkultúránk erősítése kapcsán. Célunk, hogy együtt tanuljunk tovább Önökkel a jövőben is. Ma már inkább azt mondjuk: Rajta! Olvassanak kritikusan és osszák meg másokkal is, küldjenek visszajelzéseket!

\footnotetext{
${ }^{1}$ Császi Erzsébet: Az első feladatok között van a népegészségügy átalakítása - Interjú dr. Vokó Zoltánnal. iLAM 2011.05.20. http://www.elitmed.hu/ilam/interjuk/az_elso_feladatok_kozott_van_a_nepegeszsegugy_atalakitasa_7543/ (Elérés: 2015.03.01.)

${ }^{2}$ Orosz Éva: Globális és hazai egészségügyi kihívások és egészségpolitikai törekvések a 21. század elején. Esély, 2009;6:3-26. http://www.esely.org/kiadvanyok/2009 6/OROSZ.pdf (Elérés: 2015.03.01.)

${ }^{3}$ Balku Eszter, Berki Júlia, Csizmadia Péter et al.: Egészségjelentés2015, Nemzeti Egészségfejlesztési Intézet, Budapest, 2015 http://www.egeszseg.hu/szakmai oldalak/assets/files/news/egeszsegjelentes-2015.pdf 25.o (Elérés: 2015.03.01.)
} 